\title{
NATO and Eurocommunism. The Fear of a Weakening of the Southern Flank from the mid-1970s to mid-1980s
}

\author{
Nikolas DÖRR
}

In December 1967, the NATO strategy, colloquially referred to as "massive retaliation", was replaced by the new strategy of "flexible response" with the document MC 14/3. The report "Future Tasks of the Alliance", prepared by the former Belgian Prime Minister and then Foreign Minister Pierre Harmel and adopted by the NATO Council in December 1967 had had a central influence on the development of this new strategy. ${ }^{1}$

In contrast to the previous massive retaliation doctrine Harmel did not see the need for military deterrence by NATO being at variance with the establishment of a form of détente with communist states. Following Harmel, security was only possible if military defence and détente went hand in hand. The report called on the Member States to bring about improvement in their relations with the Soviet Union and other communist states. Ideally, these efforts should be coordinated between the NATO countries to prevent a disparate alliance.

While détente was propagated outwardly, massive conflicts emerged within the Alliance in the 1970s that contributed to a significant weakening of NATO. This crisis peaked with the Eurocommunist electoral successes from the mid to the late 1970 s. $^{2}$ Conflicts such as the withdrawal of France from the military integration of NATO in 1966; the "Cod Wars" between the United Kingdom and Iceland (partially also between the Federal Republic of Germany and the mentioned countries); the Turkish invasion and occupation of Northern Cyprus and the following tensions between Greece and Turkey, with the exit of Greece from the military integration of NATO in 1974; the withdrawal of the British forces from Malta; the emergence of Soviet-sponsored regimes of Arab socialism in the Southern Mediterranean; the Middle East conflict and the ongoing crisis between the United Kingdom and Spain over Gibraltar weakened NATO. ${ }^{3}$ With the exception of Iceland these crises invariably concerned the Mediterranean and thus the Southern flank of the Western defence

1. The Future Tasks of the Alliance. Report of the Council - "The Harmel Report", in: http://www.nato.int/cps/en/natolive/official_texts_26700.htm (02.04.2014).

2. For a definition of Eurocommunism, cf. M. AZCARATE, What is Eurocommunism?, in: G.R. URBAN (ed.), Eurocommunism. Its Roots and Future in Italy and Elsewhere, Temple Smith, London, 1978, pp.13-31. See also H. KISSINGER, Communist Parties in Western Europe. Challenge, in: A. RANNEY, G. SARTORI (eds), Eurocommunism. The Italian Case, American Enterprise Institute for Public Policy Research, Washington DC, 1978, pp.189-193.

3. Cf. D. LEEBAERT (ed.), European security. Prospects for the 1980s, Lexington Books, Lexington (Mass.), 1979, pp.107-134. 
alliance, which had been defined in an internal NATO report from 1974 as "one of the world's most politically unstable areas". ${ }^{4}$

In the following, the image of Eurocommunism as a threat to NATO will be closely examined. It will be shown that it represented the background for a great uncertainty in the security policy of NATO as well as parts of the Federal Republic of Germany and the United States of America. Eurocommunism was less of a real threat to NATO. The term was rather used as a projection screen of fears during the Cold War. In this way the concept was highly politicized. This led to misperceptions in the analysis of Eurocommunist parties by NATO and conservative politicians in the member states of the Alliance.

This article is based on research in the NATO Archives in Brussels, the Archive of Social Democracy in Bonn, the Archive for Christian Social Policy in Munich, the Archive for Christian Democratic Policy in St. Augustin, the Political Archive of the Federal Foreign Office in Berlin, the British National Archives in Kew, the Gerald R. Ford Presidential Library in Ann Arbor and the Jimmy Carter Presidential Library in Atlanta.

\section{The threat to NATO from within}

The success of the Eurocommunist parties in the West led not only to political but also military uncertainties. ${ }^{5}$ In the most important NATO Member States in Europe, apart from the United Kingdom and the Federal Republic of Germany, the communist parties of Italy and France experienced electoral successes. These parties were successful at the municipal, regional and state level and could also boast an increase of membership. In Spain, a country that was particularly important for Western European security and a potential NATO Member State, the Communist Party with its charismatic leader Santiago Carrillo was also a factor to consider. At the same time, there was uncertainty about the strength of the Communists in the post-dictatorial NATO countries Portugal and Greece. Therefore, the NATO leaders acknowledged, at the height of the Eurocommunist movement, that the observation and analysis of the political situation in these countries was a top priority. ${ }^{6}$

4. NATO Archives/Archives de l'OTAN in Brussels, Defence Planning 1971-1975, Flanks, DPC/ D(74)9, Alliance Defence Problems for the Planning Committee, Report of the Defence Planning Committee, 07.06.1974.

5. Cf. R. GODSON, S. HASELER, "Eurocommunism”. Implications for East and West, Macmillan, London, 1978, pp.104-112.

6. GFPL [Gerald R. Ford Presidential Library, Ann Arbor], White House Central File, Subject File, International Organizations, IT 50 North Atlantic Treaty Organization 7/1/75 (executive) to IT 52 Organization of American States, IT 50 NATO 7/1/75-12/31/75, Box 5, Press release "President's Meeting with NATO Secretary General Joseph Luns", 10.02.1976. 


\begin{tabular}{|l|c|c|c|}
\hline \multirow{3}{*}{ Electoral strength of communist parties in NATO Member States } \\
Country & Year of election & Percentage of CPs & Seats in Parliament \\
\hline Belgium ${ }^{8}$ & 1977 & 1,1 & 0 \\
\hline Canada & 1979 & 0,2 & 0 \\
\hline Denmark & 1977 & 10,3 & 19 \\
\hline France & 1978 & 20,6 & 86 \\
\hline West Germany & 1976 & 0,5 & 0 \\
\hline Greece & 1977 & 12,1 & 13 \\
\hline Iceland & 1978 & 23,0 & 9 \\
\hline Italy & 1976 & 36,0 & 234 \\
\hline Luxembourg & 1979 & 6,9 & 3 \\
\hline Netherlands & 1977 & 2,6 & 2 \\
\hline Norway & 1977 & 5,2 & 41 \\
\hline Portugal & 1976 & 16,1 & 27 \\
\hline Spain & 1977 & 15,0 & 0 \\
\hline Turkey & 1977 & 0,1 & 0 \\
\hline United Kingdom & 1979 & 0,2 & 0,2 \\
\hline USA & 1976 & & \\
\hline
\end{tabular}

Since French President Charles de Gaulle had decided to withdraw from the military integration of NATO in 1966, the military strength of Italy - the country had

7. These are the results of the parliamentary elections in the heyday of Eurocommunism from the mid to the late 1970s. In plurality voting systems only the result of the first election round is shown. The result of the United States is based on the presidential election in 1976.

8. Belgium: Communist Party of Belgium, Canada: Communist Party of Canada and Communist Party of Canada (Marxist-Leninist), Denmark: Communist Party of Denmark, Socialist People's Party and Left Socialists, France: French Communist Party, West Germany: German Communist Party, Communist Party of Germany (AO) and Communist League of West Germany, Greece: Communist Party of Greece and Progress and Left Forces Alliance, Iceland: People's Alliance and Communist Party of Iceland (Marxist-Leninist), Italy: Italian Communist Party, Proletarian Democracy and Proletarian Unity Party, Luxembourg: Communist Party of Luxembourg and Independent Socialist Party, Netherlands: Communist Party of the Netherlands and Pacifist Socialist Party, Norway: Socialist Left Party, Red Electoral Alliance and Communist Party of Norway, Portugal: Portuguese Communist Party and People's Democratic Union, Spain: Communist Party of Spain, People's Socialist Party, Catalan Left-Democratic Electoral Front and Euskadiko Ezkerra, Turkey: Workers Party of Turkey, United Kingdom: Communist Party of Great Britain and Workers Revolutionary Party, USA: Communist Party USA and Socialist Workers Party.

9. Spain became a Member State of NATO on 30 May 1982. 
an army of 362,000 soldiers in $1978 / 79^{10}$ - gained in importance. However, the country's membership in NATO would have been in danger, if Italy got a communist government. Hans-Christian Pilster, former head of the Amt für Militärkunde of the Bundeswehr, mentioned the good relations between the administration of communistruled cities and regions in Italy and the military departments, thus stressing communist influence within the army. In addition, the Communist Party of Italy had become increasingly attractive for the lower ranks of the army since the early 1970s. ${ }^{11}$

Although the Italian government, due to the precarious financial situation in the late 1970 s, spent only 2.4 percent of its gross domestic product on its military budget, and the Italian army used mostly outdated machinery and weapons, Italy was vital for NATO. Not only had Italy a large number of soldiers at its disposal, the Italian army was also a leading force in some special areas within the Western military alliance that were considered central to the security of the Mediterranean and the Alps in the event of an attack by the armies of the Warsaw Pact. These included mainly the speedboats of the Italian Navy, the special unit of the combatant divers as well as the parachute and mountain troops. ${ }^{12}$

In addition to the Italian army, the logistical and operational function of Italian territory was seen as essential for NATO. The VI US Fleet, for example, was stationed in Gaeta and the fifth tactical air fleet (ATAF) of NATO had its base in Vicenza. The island of La Maddalena, which belongs to Sardinia, served as a base for nuclearpowered submarines. The NATO headquarters for Southern Europe (AFSOUTH) was located in Naples and the NATO Defence College, the central training institution of the Alliance, was stationed in Rome. In several bases, most of which were located in the Northeast of Italy, nuclear weapons of NATO were stored as part of the nuclear sharing concept. These nuclear weapons would have been provided in the case of an attack.

\section{Italian Eurocommunism as an internal threat to NATO}

The supposed threat to Western security by the Communist Party of Italy was one of the central themes within the NATO's bodies before the Italian parliamentary elections of 20 June 1976. A possible government involvement would have given the Partito Comunista Italiano (PCI) the right to name high ranking members of the government. Ministers and Secretaries of State from the Italian Communist Party could have there-

10. Cf. D.S. LUTZ, A. POTT, Südeuropa. Eurokommunistisches Problemfeld der NATO?, in: D.S. LUTZ (ed.), Eurokommunismus und NATO. Zukunftsprobleme europäischer Sicherheit, Osang, Bonn, 1979, p.17.

11. Cf. H.C. PILSTER, Eurokommunismus. Eine Gefahr für die Sicherheit der NATO?, in: Politische Studien, 247(1979), p.462.

12. Cf. G. SCHREIBER, Italiens Marine 1978. Bestandsaufnahme und Ausblick, in: Marine-Rundschau, 1(1979), pp.42-44; R. MENNEL, Die wehrgeographische Bedeutung Italiens für die Südflanke der NATO, in: Wehrkunde, 3(1974), p.143. 
fore attended meetings of NATO committees. NATO Officials were especially anxious that communist office holders would take part in the meetings of the NATO Nuclear Planning Group (NPG). The NPG was created in 1966 for the coordination of the nuclear weapons strategy of the Alliance. ${ }^{13}$ Thus the NPG automatically belonged to the most secret and most important NATO bodies and was obviously no place for the participation of communists, in the opinion of NATO officials.

Although the PCI leadership had announced before the election that the party was not interested in the Ministry of Defence in case the Communists would be included in the government, the fears within NATO were thereby hardly dismissed. As dramatically described in the words of Hans-Christian Pilster, NATO seemed for the majority of security policymakers impossible with a communist participation:

"Whether to proceed to an amputation or an aseptic treatment of the infected member of the Alliance will be a pragmatic decision". ${ }^{14}$

"Eurocommunism" was extensively discussed in the North Atlantic Assembly, which today is the NATO Parliamentary Assembly. The topic of "Take-over of governmental power by the Communist Parties" was set on the agenda of the 22nd Annual Meeting of the North Atlantic Assembly from 14 to 19 November 1976 in Williamsburg, Virginia. In a resolution, which had been drafted by the Political Committee, the majority of the General Assembly spoke out against the government participation of communist parties in any NATO member states:

"The General Assembly [...] is of the opinion that with regard to the public opinion the necessary continuation of defence policy would be affected negatively in the West, if one were to believe the declarations of some of the mentioned communist parties". ${ }^{15}$

The Resolution of the annual General Assembly of the Atlantic Treaty Association (ATA), NATO's most important lobby group, stressed in August 1977 in Reykjavik that Eurocommunist parties had to be analysed with caution because they were "masters of deception". ${ }^{16}$ General Alexander Haig, former NATO Supreme Allied Commander for Europe and later US Secretary of State under President Ronald Reagan, stated in an article a few months after the Italian parliamentary election that Western

13. "The NPG is the essential instrument by which the NATO governments can develop policies and guidelines for military planning and procedures for effective consultation and decision-making regarding the possible defensive use of nuclear weapons by NATO". Communiqué of the NATO Nuclear Planning Group, adopted at the 15th Ministerial Meeting on 11-12. June 1974 in Bergen, Norway in: ASD [Archive of Social Democracy in the Friedrich-Ebert-Foundation, Bonn], Bruno Friedrich papers, NATO materials, 1/BFAA001151, Bulletin of the Federal Government, 22.06.1974, p.743.

14. H.C. PILSTER, op.cit., p.468.

15. Information of the German Delegation to the North Atlantic Assembly in: ASD, Bruno Friedrich papers, NATO materials, 1/BFAA001151, Bulletin of the German Bundestag 8/27, 30.12.1976, p.6.

16. JCPL [Jimmy Carter Presidential Library, Atlanta], White House Central File, Subject File, International Organizations, Executive IT 45/A 1/20/77-1/20/81 through Executive IT 67 6/1/78-1/20/81, IT 67 6/1/77-12/31/77, Box IT-5, Final Resolution of the XXIIIrd Annual Assembly of the Atlantic Treaty Association, 26.-29.08.1977, p.2. 
Europe did no longer feel "the impulse of fear" towards communism. ${ }^{17}$ Nearly a year later, he warned in a speech at the Assembly of the Western European Union (WEU) in Paris that in the case of a communist government participation in NATO Member States severe problems would arise regarding the submission of secret security information to these countries. ${ }^{18}$ In addition, these communist infiltrated governments would play a reduced role in Western security policy and would also encourage for cuts in the defence budget. ${ }^{19}$

Besides the potential participation of Eurocommunist parties in the government, the possible inclusion of (Euro)communist delegates in the North Atlantic Assembly was perceived as a threat to the security of NATO. The North Atlantic Assembly discussed the issue which had become acute by the addition of two communist delegates from Italy and one from France to the Committee on Defence and Armaments of the WEU Parliamentary Assembly. In the wake of the meeting in Reykjavik in early April 1977 the International Secretariat prepared a paper which indicated that in the case of a proportional composition of the NATO Parliamentary delegations, communists from Italy, France, Portugal, Greece and Iceland would be allowed to participate in the meetings. The conservative politician and former German Minister of Justice Richard Jaeger, who also gave a detailed presentation on the "dangers" of Eurocommunism, voiced the opinion that the work of the North Atlantic Assembly would be meaningless if communists participated in it. ${ }^{20}$ Communists in the Parliamentary Assembly of NATO would be a "Contradictio in adjecto". Jaeger, who was also President of the Atlantic Treaty Association, preferred the abolition of the Assembly rather than allowing communist delegates to participate, as, in his view, this was still better than to "assist the enemy." Especially German Social Democrats had previously argued for a proportional representation of delegates in the Assembly including communists. The accusation of the former General Secretary of the Christian Democratic Union (CDU) and then Chairman of the Konrad-Adenauer-Foundation Bruno Heck that some Social Democrats dreamed of a new security policy including Eurocommunists against the United States was, however, clearly exaggerated. ${ }^{21}$

17. Alexander Haig quoted in: Amerika-Dienst der US-Botschaft Bonn, in: ASD, Eugen Selbmann papers, NATO, 91/1, Oktober 1976, p.1.

18. Previously there had been two NATO Member States with communist participation in government. The participation of the People's Alliance in the Icelandic government deemed irrelevant because Iceland did not provide troops for NATO. In post-revolutionary Portugal no secret information had been forwarded to the government for a certain period.

19. Haig warnt vor dem Eurokommunismus, in: Süddeutsche Zeitung, 01.12.1977.

20. Jaeger saw the danger of deception by Eurocommunist delegates. They would receive sensitive information in the meetings which they might transmit to Moscow afterwards. Eurocommunist delegates would also try to influence decisions of the North Atlantic Assembly for the purposes of the Soviet Union. In this way they would act like a Trojan horse. ACSP [Archive for Christian Social Policy in the Hanns-Seidel-Foundation, Munich], Richard Jaeger papers, A:291, speech manuscript for the meeting of the for the meeting of the Standing Committee of the North Atlantic Assembly on 1/2 April 1977 in Reykjavik, Iceland.

21. ACDP [Archive for Christian Democratic Policy, St. Augustin], Bruno Heck papers, 01-022, 015/2, Press and Information Office of the Federal Government, SWR II, Bruno Heck on issues of Eurocommunism, July 31, 1976, 02.08.1976. 
A long discussion about the acceptance of communists in the Assembly followed, in which, as expected, the representatives of the conservative, christian democratic and liberal parties were in opposition to a communist involvement in NATO bodies. Finally, the decision was taken by the Assembly to maintain the status quo of exclusion of communists as long as possible. ${ }^{22}$ But since the national parliaments were responsible for the nomination of the delegates, this could only be interpreted as a recommendation. Eventually, it took until 1984 before the first communist delegates could take their seats in the North Atlantic Assembly.

\section{The United States, NATO and Eurocommunism}

Against the background of NATO's crisis mentioned above, the increasing popularity of Eurocommunist parties in Western Europe was regarded with particular concern in the United States. As a result of the success of the Italian Communists in the regional elections of 1975 the House of Representatives prepared a report on the situation of NATO's Southern flank. For this purpose, a group of members of the House Committee on International Relations was sent to Europe from 5 to 27 August 1975. They were supposed to gain information about the strength of Eurocommunist parties in the European NATO countries and to discuss the topic in the NATO headquarter SHAPE (Supreme Headquarters Allied Powers Europe) in Belgium. ${ }^{23}$ Chairman of the delegation was the Democratic Congressman Leo J. Ryan.

The report of the delegation stressed that the strength of the communists was a problem for NATO especially in Italy and Portugal. In addition, the Western Alliance was significantly weakened by the withdrawal of Greece from the military integration of NATO and the anti-American stance of the Turkish government after the establishment of the arms embargo by the United States Congress in the wake of the Cyprus conflict. Similarly, the US delegation described the foreseeable end of the Franco dictatorship in Spain as a factor of uncertainty for Southern Europe. ${ }^{24}$

In addition to these political threats to the alliance, an economic one existed. Due to the worldwide recession after the first oil price crisis, the military budgets of all NATO member countries were under great pressure.

Finally, a psychological component was added. Ryan claimed in his report that the détente policy had led to a dilution of the original mission of NATO in the eyes

22. ACSP, Richard Jaeger papers, A:291, U 40 SC (77) 25 - Minutes of the meeting of the Standing Committee held in Reykjavik, Iceland, 01./02. April 1977, International Secretariat, p.13.

23. JCPL, White House Central File, Subject File, International Organizations, Executive IT 45/A 1/20/77-1/20/81 through Executive IT 67 6/1/78-1/20/81, IT 67 1/20/77-5/31/77, Box IT-5, NATO: Pressures from the Southern Tier. Report of a Study Mission to Europe, October 1975.

24. The Spanish dictator Francisco Franco Bahamonde died just three months after the European tour of the Congressmen on 20 November 1975 in Madrid. 
of many Western Europeans but also in North America. ${ }^{25}$ Congressman Ryan recommended that the United States should increase its pressure on the European NATO partners so that they would contribute more to the costs of the alliance in the future.

In the case of Portugal the report recommended a defensive position of US diplomacy until the post-revolutionary conflicts calmed down. In contrast to Portugal the US government should be very active in Spain and should push for a NATO membership as soon as possible after the expected death of Franco. Concerning Italy the political and military strategists in Washington DC were advised to develop a scenario in which the Italian Communists achieved the majority in parliament and the government. Ryan considered this probable and therefore recommended a suitable preparation.

The report referred to particularly worrisome rumours that the Italian Communists would receive up to 54 million US dollars annually from the Soviet Union. The report therefore demanded a more precise observation and analysis of the Communist Party of Italy:

"We can no longer pretend that the PCI does not exist, officially. The attitude of the PCI toward the United States just might be influenced to some extent by our attitude toward the PCI".

The delegation of congressmen therefore argued for direct talks with high-ranking officials of the Italian Communists to gain better information about the PCI. This idea was finally rejected on the advice of the US Embassy in Rome.

The US delegation found the most explicit rejection of a communist participation in government in Italy at the NATO headquarter SHAPE:

"There is a considerable resistance at NATO headquarter to the idea that NATO should change to allow for future changes in the governments of the southern tier countries, including possible participation of indigenous Communist parties. The view was expressed that NATO should not be like a salad bar where each country can take and give only what it wants or finds convenient". ${ }^{26}$

NATO leaders in Brussels considered the military situation to be good on the Northern flank, improving in the centre and significantly weakened on the Southern flank.

Following the success of the PCI in the parliamentary election of 20 June 1976 the intelligence service of the US State Department, the Bureau of Intelligence and Research (INR) headed by the Assistant Secretary of State for Intelligence and Research Harold H. Saunders, expected in a memorandum to Secretary of State Henry Kissinger that Italy would reduce its contribution to NATO because of the communist influence on the government of Prime Minister Giulio Andreotti. ${ }^{27} \mathrm{He}$ was convinced that, even without taking part in Andreotti's government, the PCI would play a greater

25. JCPL, Report of a Study Mission to Europe, October 1975, op.cit., p.1.

26. Ibid., pp.2-12.

27. The PCI came in second, gaining 227 seats in the Chamber of Deputies $(34,4 \%)$ and 116 seats in the Senate of the Republic $(33,8 \%)$. 
role in the foreign and security policy of Italy. ${ }^{28}$ Despite the assumed increased influence of the PCI on foreign and security policy the INR did not expect an Italian withdrawal from NATO. That was also in accordance with the party program of the Communists which stated that any unilateral withdrawal from one of the two military blocs would endanger the balance of power and détente. ${ }^{29}$ However, it was assumed that the PCI would advocate further cuts in the defence budget and a restructuring of NATO in order to minimize the dominance of the United States. Only increased Soviet pressure on Tito's Yugoslavia would move the PCI into a more US and NATOfriendly position. Due to the veto power of the PCI in Parliament the conservative Prime Minister Andreotti could no longer appoint outspoken anti-communists to high ranking positions of the military and intelligence services. In addition, Saunders believed that the communists might use their power in Parliament and the relevant committees in order to influence the necessary restructuring of the Italian military intelligence service Servizio Informazioni Difesa (SID). ${ }^{30}$

The Memorandum of the State Department intelligence service acknowledged that the US administration had regular contacts with the Italian Christian Democrats and the Vatican, while there was only an irregular relationship with the Socialist Party. Concerning the Italian Communists there were only rare contacts on the lowest level. The INR saw this as disadvantageous. ${ }^{31}$

In the most populous NATO country in Europe, the Federal Republic of Germany, a significant percentage of the population expected a reduced defence capability of NATO, when communists would move into the governments of NATO Member States. The US Information Agency collected data on this topic in late 1977 using a questionnaire, which looked at the attitudes to Eurocommunism and its relationship with NATO. ${ }^{32}$ US President Jimmy Carter's National Security Advisor Zbigniew Brzezinski and the expert for Western Europe in the National Security Council Robert E. Hunter took part in the development of the questionnaire. ${ }^{33}$

28. GFPL, National Security Adviser, Presidential Country Files for Europe and Canada, Country File: Italy (1), Italy (9), Box 8, Briefing Memorandum from Harold H. Saunders to Henry Kissinger, 02.12.1976, pp.2-8.

29. Cf. N. KOGAN, The Italian Communist Party. The Modern Prince at the Crossroads, in: R.L. TÖKÉS (ed.): Eurocommunism and Détente, New York University Press, New York, 1978, p.124.

30. GFPL, National Security Adviser, Presidential Country Files for Europe and Canada, Country File: Italy (1), Italy (9), Box 8, Briefing Memorandum from Harold H. Saunders to Henry Kissinger, 02.12.1976, pp.8 f.

31. Cf. R.N. GARDNER, Mission Italy. On the Front Lines of the Cold War, Rowan \& Littlefield, Lanham, 2005, pp.10 and 113-121.

32. JCPL, White House Central File, Subject File, International Organizations, Executive IT 45/A 1/20/77-1/20/81 through Executive IT 67 6/1/78-1/20/81, IT 67 6/1/77-12/31/77, Box IT-5, USIA Survey Questionnaire on Eurocommunism Issues, 01.11.1977.

33. JCPL, White House Central File, Subject File, International Organizations, Executive IT 45/A 1/20/77-1/20/81 through Executive IT 67 6/1/78-1/20/81, IT 67 6/1/77-12/31/77, Box IT-5, Memorandum from Gregory F. Treverton to Zbigniew Brzezinski, November 1977; Executive IT 45/A 1/20/77-1/20/81 through Executive IT 67 6/1/78-1/20/81, IT 67 6/1/77-12/31/77, Box IT-5, Harold E. Engle to Robert E. Hunter, 04.11.1977. 
The survey was conducted in November 1977 in West Germany. Following a few initial questions on the attitude towards the United States and NATO, the communist parties in France, Italy, Portugal and Spain had to be evaluated in their relation to the Soviet Union by the survey participants. It was also asked for which side the French Communist Party would decide in the event of a crisis between the West and the Soviet Union. Three questions were related to the effects of a communist government participation in France vis-à-vis the Federal Republic of Germany, the European Community and NATO. It was also asked whether the United States would use its influence to prevent communist parties in Western Europe from participation in government. ${ }^{34}$

Although the result of the survey showed that West Germans still had a high level of confidence in NATO and the role of the United States in general. Only 37 percent of respondents would have confidence in the US commitment to the defence of Western Europe if the French Communists participated in the Government. 36 percent of the respondents stated that they would no longer trust the guaranteed security by NATO and the United States in such a case. In addition, 40 percent of the respondents were convinced that NATO would be weakened by a communist government involvement. ${ }^{35}$

\section{How to deal with the Italian Communists? The Western powers and the G7 Summit in Puerto Rico 1976}

The main NATO Member States USA, Great Britain, Federal Republic of Germany and France responded initially reluctant on the political level after the high gains of the PCI in the parliamentary elections of 20 June 1976. The G7 states agreed that the unclear situation after the elections should not be made more difficult by public intervention. The governments decided to discuss the subject behind closed doors at the G7 summit in Puerto Rico that took place a week after the Italian elections. ${ }^{36}$ The summit participants were Gerald Ford (USA), James Callaghan (UK), Helmut Schmidt (West Germany), Valéry Giscard d'Estaing (France), Takeo Miki (Japan), Pierre Yves Elliott Trudeau (Canada), Aldo Moro (Italy) and their staffs. The representatives of the United States, Britain, West Germany and France had agreed to

34. JCPL, White House Central File, Subject File, International Organizations, Executive IT 45/A 1/20/77-1/20/81 through Executive IT 67 6/1/78-1/20/81, IT 67 6/1/77-12/31/77, Box IT-5, USIA Survey Questionnaire on Eurocommunism Issues, 01.11.1977, pp.3 f.

35. JCPL, White House Central File, Subject File, International Organizations, Executive IT 45/A 1/20/77-1/20/81 through Executive IT 67 6/1/78-1/20/81, IT 67 1/1/78-5/31/78, Box IT-5, Memorandum from Gregory F. Treverton to Zbigniew Brzezinski, 04.01.1978.

36. Cf. D. BASOSI, G. BERNARDINI, The Puerto Rico Summit of 1976 and the end of Eurocommunism, in: L. NUTI (ed.): The Crisis of Détente in Europe. From Helsinki to Gorbachev, 1975-1985, Routledge, New York, 2009, pp.256-267; A. VARSORI, Puerto Rico (1976). Le potenze occidentali e il problema comunista in Italia, in: Ventunesimo Secolo, 16(2008), pp.89-121. 
arrive a few hours before the delegations from Italy, Canada and Japan in order to discuss the sensitive matter in a private circle. ${ }^{37}$ Officially, the topic "Italy" was not placed on the agenda. ${ }^{38}$ However, it was discussed extensively in private. ${ }^{39}$ It was widely agreed within the group of Ford, Callaghan, Schmidt and Giscard d'Estaing that a Communist involvement in the Italian government would cause problems for the coherence of NATO.${ }^{40}$ Chancellor Schmidt stressed particularly the dangers for the Italian economy. Finally, the parties agreed that they would not award international loans to Italy if the PCI was to become officially a part of the government. It was further arranged that the discussions on Italy were not supposed to reach the public.

Nevertheless, the content of the conversation became publicly known shortly after the end of the summit. Chancellor Schmidt had a non-public background discussion with seven American business journalists immediately after the Puerto Rico meeting. Although it had been accepted before the interview that the journalists were not supposed to publish the information directly, one of the participants ignored the agreement. ${ }^{41}$ The following publication of the secret talks in the Washington Post provoked reactions in all affected countries. On the political level, Ford, Callaghan and Giscard d'Estaing tried to distance themselves from the German Chancellor. The French President, a close friend of Schmidt, published a clear statement via the Elysée Palace. ${ }^{42}$ Giscard d'Estaing stressed that the government of the French Republic rejected external interference in the internal affairs of sovereign states. However, considering the continuous involvement of the French government in the affairs of sovereign African states and the politics of "Françafrique" Giscard d'Estaing's statement appeared implausible. In addition, the French president reaffirmed the arrangements concerning Italy after the summit of Puerto Rico. However, this confirmation was done in a non-public conversation with Schmidt in Hamburg. In addition to Giscard d'Estaing US President Ford, his National Security Adviser General Brent Scowcroft and Defence Secretary Donald Rumsfeld also expressed satisfaction with

37. PAFFO [Political Archive of the Federal Foreign Office], B 150, Vol. 348, Note about the conversation of Chancellor and Minister of Foreign Affairs with Secretary of State Kissinger on May 23, 1976 by Dr. Jürgen Ruhfus, 24.05.1976.

38. The official agenda included the following: economy and balance of payments problems (27.06), international Trade and East-West economic relations (28.06.), North-South dialogue and energy (28.06.). PAFFO, B 150, Vol. 350, Notes on Summit talks in Dorado Beach Hotel, San Juan, Puerto Rico from 27 to 28 June 1976 by Dr. Dieter Hiss, 07.05.1976.

39. The National Archives (Kew), Prime Minister's Office: Correspondence and Papers, 1974-1979, PREM 16/978, Italy, Italian political situation: UK/US/French/German contact on aid to Italy and reaction to electoral gains by the Communist Party of Italy, Minutes of the British government delegation on the occasion of a dinner of Heads of State and/or Government and Foreign Ministers of the United States, Great Britain, France and the Federal Republic of Germany by E.A.J. Ferguson, 28.06.1976, p. 1.

40. Der Spiegel, 26.07.1976, p.19.

41. Cf. H. SOELL, Helmut Schmidt, vol.2, 1969 bis heute. Macht und Verantwortung, DVA, Munich, 2008, pp.453 f.

42. Cf. F. HEURTEBIZE, Le péril rouge. Washington face à l'eurocommunisme, PUF, Paris, 2014, pp. $152 \mathrm{f}$. 
the agreements of Puerto Rico behind closed doors. ${ }^{43}$ Nevertheless, the West German Chancellor received public support only by the deputy press secretary of the White House John G. Carlson. ${ }^{44}$

Schmidt's remarks immediately led to criticism by the Italian communists and the French left. ${ }^{45}$ Pierre Mauroy, the second man of the Parti Socialiste behind François Mitterrand and later Prime Minister, accused Schmidt of "American opinions" - a grave insult in the French left of the 1970s. ${ }^{46}$

Domestically, however, the statement of the Chancellor was well chosen. With his criticism of a government participation of the PCI in Italy Schmidt presented himself as tough and anti-communist in his foreign policy only a few months before the West German parliamentary elections in October 1976. Before that the conservative opposition had repeatedly attacked him and the Social Democratic Party (SPD) for being too lax against the Italian Communists. ${ }^{47}$ Prominent politicians of the CDU and CSU like Helmut Kohl, Franz Josef Strauss and Karl Carstens pointed out the dangers of Italian Eurocommunism to NATO and the European Community. ${ }^{48}$ The Chancellor had now clearly taken a stand and refuted the criticism of the conservative opposition. ${ }^{49}$ Internationally, however, the arrangements of Puerto Rico showed only minor effects. Western governments were aware that Italy needed financial support and that the PCI would have benefited from a further deterioration of the economic situation. Nevertheless, behind the scenes continues pressure was put on the Democrazia Cristiana to prevent an official government coalition with the Communists and thus the realization of the communist strategy of the compromesso storico.

Ten days after the end of the Puerto Rico summit the four senior diplomats Helmut Sonnenfeldt (USA), Reginald A. Hibbert (United Kingdom), Günther van Well (West Germany) und Yves Carnac (France) met in Paris. They discussed options to operationalize the decisions regarding Italy. It was agreed that the Italian Christian Democrats should be convinced of comprehensive reforms in the field of economic and financial policy. It was also agreed that the four governments should contact Italian decision-makers on private channels to dissuade them from a possible coalition

43. PAFFO, B 150, Vol. 351, Telex from the German Embassy in Washington to the Foreign Office about the conversation of the Federal Minister of Defence with President Ford, Secretary of Defence Rumsfeld and General Scowcroft on July 2, 1976, 13.07.1976.

44. ASD, Bruno Friedrich papers, Italy - Italian Communist Party, 1/BFAA001561, Bulletin of the Federal Press Office, 19.07.1976.

45. Cf. I segreti della politica internazionale, intervista a Sergio Segre, in: M. MAGGIORANI, P. FERRARI (eds), L'Europa da Togliatti a Berlinguer. Testimonianze e documenti, 1945-1984, Il Mulino, Bologna, 2005, pp.1681 f.

46. ADS, Bruno Friedrich papers, International relations - Italy, 1/BFAA001530, Federal Press Office: Pierre Mauroy's remarks about Chancellor Schmidt's statements regarding the economic aid to Italy, 21.07.1976.

47. In fact, West German Social Democrats and Italian communists established close ties in 1967 which were continued until the dissolution of the PCI in 1991.

48. Cf. N. DÖRR, Die Auseinandersetzungen um den Eurokommunismus in der bundesdeutschen Politik 1967-1979, in: Jahrbuch für Historische Kommunismusforschung, 2012, pp.224-228.

49. Der Spiegel, op.cit., pp.19 f. 
between Communists and Christian Democrats..$^{50}$ In the next days and weeks US Ambassador to the United Nations William W. Scranton and Henry Cabot Lodge, Jr., Special Envoy of the United States government to the Vatican, were commissioned, amongst others, for this purpose by Secretary of State Henry Kissinger. Schmidt informed the US government that he used his contacts to inform the Italian Socialists and Social Democrats about the opinion of the four governments. ${ }^{51}$

With the formation of the Christian Democratic government of Prime Minister Giulio Andreotti at the end of July 1976 the primary objective of Western states was achieved. The government was indeed dependent on abstinence, later also on the active support of the communists in Parliament, officially, however, the PCI was not part of the government coalition. In the following months, the four governments publicly supported Andreotti to strengthen him against the dependence on the Communist Party.

After General Secretary Enrico Berlinguer had demanded that the PCI become an official part of the government the Italian situation again became a problem for international politics in January $1978 .{ }^{52}$ But the entry of the PCI into the Italian government was finally denied, also due to massive pressure by the government of US President Jimmy Carter. ${ }^{53}$

\section{Conclusion}

After the Italian parliamentary election in June 1979 the topic "Eurocommunism" became less important in the debate about Western security. ${ }^{54}$ Eurocommunist parties suffered electoral defeats and losses of members. With the decay of Eurocommunist solidarity between the parties the concept lost its attraction. The ideology of the "Third Way" could not be realized in practice. In the early 1980s the Eurocommunist parties had to make a decision between orthodox communism and social democratization. The French and Japanese Communist parties went back to an old-fashioned MarxismLeninism while the Italian Communists gradually transformed into a social democratic party. That process ended in late January 1991 with the conversion to the Partito Democratico della Sinistra (PDS). Large parties such as the Communist Party of Spain split and thereby lost influence. One of the former leaders of the Eurocommunist movement and former Secretary-General of the Spanish Communists Santiago

50. PAFFO, B 150, Vol.351, Note on the proposals for consultation with Italian personalities associated with the formation of a government and the drafting of a government program, 09.07.1976.

51. Ibid., Notes on the conversation of Federal Chancellor and Federal Minister with President Ford and Secretary of State Kissinger on July 15, 1976, 15.07.1976, pp.4-5.

52. Cf. S. PONS, Berlinguer e la fine del comunismo, Einaudi, Turin, 2006, pp. $122 \mathrm{f}$.

53. JCPL, National Security Affairs-Brzezinski Material, Country File, Italy 5/78-Ivory Coast 1/77-1/81, Box 39, Italy 6-8/80, Declaration of the State Department from January 12, 1978.

54. The Communist Party of Italy lost 26 seats in the Chamber of Deputies and 7 seats in the Senate of the Republic. 
Carrillo was even expelled from the party in $1985 .{ }^{55}$ Therefore Eurocommunism as a threat for NATO became slowly but surely obsolete. ${ }^{56}$

Finally, the acceptance of communist delegates to the NATO Parliamentary Assembly in 1984 passed without major resistance. ${ }^{57}$ The current Italian President Giorgio Napolitano, a protagonist of the Eurocommunist wing of the PCI, was one of them. Napolitano stressed in the first speech of a Communist delegate in the NATO Parliamentary Assembly on November 16, 1984 that there was a consensus between the Italian Communists and all other members of the parliament in condemning the Soviet invasion of Afghanistan and the expansionist foreign policy of the Soviet Union. ${ }^{58}$ One of the leading experts of the Social Democratic Party of Germany on security policy Karsten D. Voigt summarised the position of the Italian Communists after the speech as followed:

"The PCI was more interested in a normalization of its relations with the United States than in initiatives to build contacts to the East". 59

The quote by Voigt reveals that at least the Italian Communists represented in the early 1980s rather a problem for the Soviet Union than for NATO. Nevertheless, as shown in the article, the participation of Eurocommunist delegates in the North Atlantic Assembly was perceived as a massive threat to the Western Alliance. Furthermore, the cohesion of NATO seemed jeopardized if Communists would be involved in governments of member states of the Alliance. In practice, however, there was no Eurocommunist strategy in the long-term. The much-cited danger of a Trojan horse called Eurocommunism which would subsequently destroy NATO from within never existed in reality. The term "Eurocommunism" was highly politicized by conservative politicians. In this way the term was used to strengthen the cohesion of the Alliance in the period of crisis in the 1970s. The warnings of Kissinger, Haig, and others are examples of this strategy.

55. Cf. N. DÖRR, Emanzipation und Transformation. Rückblick auf den Eurokommunismus, in: Osteuropa, 5-6(2013), pp.266f.

56. Cf. A. BROGI, Confronting America. The Cold War between the United States and the Communists in France and Italy, The University of North Carolina Press, Chapel Hill, 2011, pp.367-381.

57. Cf. E.D. SHERWOOD, American Foreign Policy towards West European Communism. The Italian and French Cases, California Seminar on International Security and Foreign Policy, Santa Monica, 1983, pp.68-72.

58. ASD, Horst Ehmke papers, Italy, 1/HEAA000461, Intervento dell'on. Giorgio Napolitano alla seduta plenaria dell'Assemblea dell'Atlantico del Nord, 16.11.1984, p.1.

59. ASD, Horst Ehmke papers, Italy, 1/HEAA000461, Summary report by Karsten D. Voigt, [1984], p. 2 . 